\title{
Ultra-High Pressure Water Jet: Baseline Report; Summary
}

\section{Topical Report July 31, 1997}

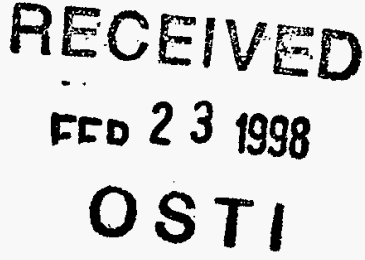

\section{1}

Work Performed Under Contract No.: DE-FC21-95MC32260

For

U.S. Department of Energy

Office of Environmental Management Office of Technology Development 1000 Independence Avenue Washington, DC 20585
U.S. Department of Energy

Office of Fossil Energy

Federal Energy Technology Center

Morgantown Site

P.O. Box 880

Morgantown, West Virginia 26507-0880

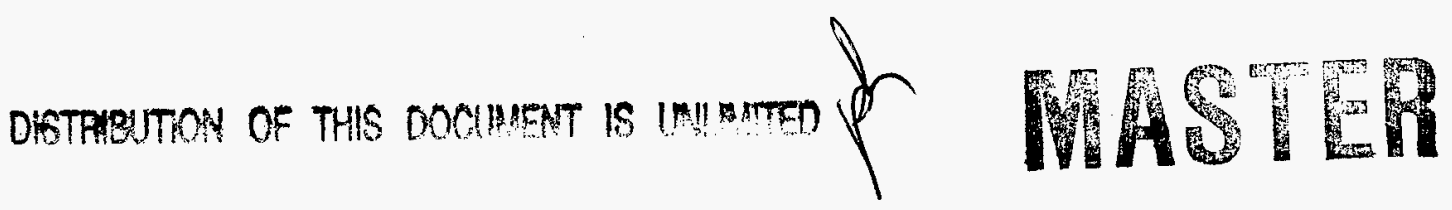

By

DIIC QUALITY TISPECTED 8

Operating Engineers National Hazmat Program

250 Airport Circle

Beaver, West Virginia 25813 


\section{Disclaimer}

This report was prepared as an account of work sponsored by an agency of the United States Government. Neither the United States Government nor any agency thereof, nor any of their employees, makes any warranty, express or implied, or assumes any legal liability or responsibility for the accuracy, completeness, or usefulness of any information, apparatus, product, or process disclosed, or represents that its use would not infringe privately owned rights. Reference herein to any specific commercial product, process, or service by trade name, trademark, manufacturer, or otherwise does not necessarily constitute or imply its endorsement, recommendation, or favoring by the United States Government or any agency thereof. The views and opinions of authors expressed herein do not necessarily state or reflect those of the United States Government or any agency thereof. 


\section{HUSKY'M ULTRA-HIGH PRESSURE WATER JET HUMAN FACTORS ASSESSMENT - BASELINE}

\section{SECTION 1 - SUMMARY}

\section{Technology Description}

The Husky ${ }^{T M}$ is an ultra high-pressure waterjet cutting tool system. The pump is mounted on a steel tube frame which includes slots for transport by a forklift. The Husky ${ }^{\mathrm{TM}}$ features an automatic shutdown for several conditions such as low oil pressure and high oil temperature. Placement of the Husky ${ }^{\mathrm{TM}}$ must allow for a three foot clearance on all sides for operation and service access. At maximum continuous operation, the output volume is 7.2 gallons per minute with an output pressure of 40,000 psi. A diesel engine provides power for the system.

\section{Key Results}

The safety and health evaluation during the testing demonstration focused on two main areas of exposure: dust and noise. Dust exposure was minimal, which would be expected due to the wet environment inherent in the technology, but noise exposure was significant. Other areas of concern were arm-hand vibration, ergonomics, heat stress, tripping hazards, electrical hazards, lockout/tagout, fall hazards, slipping hazards, hazards associated with the high pressure water, and hazards associated with air pressure systems.

\section{SECTION 2 - HEALTH AND SAFETY EVALUATION}

\section{General Safety and Health Concerns}

Safety and health issues of concern included tripping hazards, electrical hazards, rotating machinery, lockout/tagout, heat stress, ergonomics, arm-hand vibration, noise, whole-body vibration, high pressure water and air systems, fall hazards, slipping hazards, dust, and communication.

\section{Industrial Hygiene Monitoring}

Ergonomically there is potential for muscle/back stress. Arm-hand vibration was not quantitatively measured, but it was readily apparent that there was exposure to armhand vibration that could potentially cause problems such as Raynaud's syndrome. Whole-body vibration was also evident and needs to be considered when placing the pump on a platform.

Heat stress was monitored using wet-bulb globe measurements and worker physiological measurements such as blood pressure, pulse, and temperature. Work/rest regimen recommendations were made in accordance with $\mathrm{ACGIH}$ recommendations.

Personal sampling was conducted on the pump and lance operator. Personal sampling results with the exception of one were below allowable levels. The production of dust is not expected due to the wet environment inherent in the operation of the technology. The one sample that showed an overexposure appeared to be due to the accumulation of wet grit on the sampling filter. Noise monitoring resulted in a dose of $108.21 \%$ or an 8-hour TWA of $90.5 \mathrm{dBA}$ for the pump operator and $875.1 \%$ or an 8 -hour TWA of $105.6 \mathrm{dBA}$ for the lance operator. This exceeds the OSHA action level of $85 \mathrm{dBA}$ and the permissible exposure level of $90 \mathrm{dBA}$. A hearing conservation program will be essential for anyone working with or around this equipment. 
Humain Factors Interface

The technology was evaluated for operator interface with Anti-C PPE for the pump operator and Saranex-coated Tyvek for the lance operator. Both operators wore a full face air purifying respirator. The operators had visibility problems while wearing the PPE due to the full face respirator, and the pump operator had difficulty during maintenance activities due to loss of tactile sensation while wearing the gloves. There was an increase in heat stress associated with the protective ensembles.

\section{SECTION 3 - TECHNOLOGY APPLICABILITY}

On observation the technology did not produce any visible dust in the atmosphere. Air monitoring did not show a significant dust level due to the wet environment associated with this technology. The waterjet did however, create a situation where grit (small pieces of blasted concrete) was sprayed up to fifty feet from the point where the waterjet was in contact with the concrete. The water spray and the spray of concrete created a spread of contaminant that was evident on other surfaces and the PPE of the operator. The flying pieces of concrete presented a severe eye hazard. After the water dries the debris that has been spread by the water spray can become a dust covering on the surface. If disturbed, especially in an enclosed environment, this dust could become an airborne contaminant and an inhalation hazard. The water lance will not be difficult to decontaminate but the Husky ${ }^{\mathrm{TM}}$ pump will need more effort.

\section{SECTION 4 - REGULATORY/POLICY ISSUES}

The site safety and health personnel where the ultra high-pressure waterjet technology is being used need to be concerned with safety and health regulations applicable to the issues discussed above. Regulations that will apply may include but not be limited to the following areas: housekeeping, electrical, machine guarding, lockout/tagout, ionizing radiation, toxic and hazardous substances, noise, respiratory protection, PPE, HAZCOM, HAZWOPER, arm-hand vibration, whole-body vibration, medical services and first aid, and eye and face protection.

\section{SECTION 5 - OPERATIONAL CONSIDERATIONS \& RECOMMENDATIONS}

Recommendations for improved worker safety and health include good housekeeping, ergonomic training and awareness, a trigger for full finger operation on the water lance, side rails on the platform where the pump is located, hand rails on the ladder leading to the platform, the use of goggles under the face shield, and a guard on the lance to keep water and debris spray from hitting the operator. Engineering controls, administrative controls, and/or hearing protection should be used for compliance with the OSHA noise standard.

Due to the outdoor testing conditions, it is recommended that noise monitoring be conducted while the technology is in use in an enclosed environment. Since Level A or Level B PPE may be required for contaminants other than alpha radiation, it is recommended that a human factors assessment be conducted for these levels of protection.

Research supported by the U.S. Department of Energy's Federal Energy Technology Center, under cooperative agreement DE-FC21-95MC32260 with the Operating Engineers National HAZMAT Program, 250 Airport Circle, Beaver, WV 25813, phone 304-253-8674, fax 304-253-7758. This report was prepared with the support of the US DOE; however, any opinions, findings, conclusions, or recommendations expressed herein are those of the author(s) and do not necessarily reflect the views of the DOE. 
M98002047

Report Number (14) DOE/mC/32260--5842

subl. Date (11) 19970731

sponsor Code (18) $\triangle 0 \varepsilon / \varepsilon m ; \Delta O \varepsilon / F \varepsilon, X F$

JC Category (19) UC-2000; UC-101, DOE/ER

DOE 